\title{
Patronage and clientelism in the fourth gospel
}

\author{
Author: \\ Abiola Mbamalu ${ }^{1}$ \\ Affiliation: \\ ${ }^{1}$ Faculty of Theology, North- \\ West University, South Africa

\section{Correspondence to:} \\ Abiola Mbamalu \\ Email: \\ abiola_uzoamaka@hotmail. \\ com

\section{Postal address:} \\ Private Bag X6001, \\ Potchefstroom 2520, \\ South Africa \\ Dates: \\ Received: 10 Sept. 2012 \\ Accepted: 15 Mar. 2013 \\ Published: 07 Aug. 2013 \\ How to cite this article: \\ Mbamalu, A., 2013, \\ 'Patronage and clientelism \\ in the fourth gospel', In die \\ Skriflig/In Luce Verbi 47(1), \\ Art. \#657, 8 pages. http:// \\ dx.doi.org/10.4102/ids. \\ v47i1.657

\section{Copyright:} \\ (C) 2013. The Authors. \\ Licensee: AOSIS \\ OpenJournals. This work \\ is licensed under the \\ Creative Commons \\ Attribution License.
}

Read online:
Patronage and clientelism as a social-scientific model is used in this article to read the fourth gospel. It is the contention of the article that this model affords the reader fresh vistas of meaning that otherwise would have remained unexplored. It is a reading amongst other readings and does not make pretensions to illuminate every segment of the fourth gospel. Rather, it selectively looks at areas where reading against the backdrop of a patron-client model illuminates the text. This reading sheds light on the greatest gift Jesus came to give, the gift of life as a beneficium, and affirms that the signs that Jesus performed are commendationes. Jesus brokers the blessings of the kingdom to those who believe in him on behalf of the father who is the ultimate patron. Jesus also challenges popular notions of patronage by performing acts reserved for slaves by, for example, washing the feet of his disciples.

Begunstiging en kliëntskap in die vierde evangelie. In hierdie artikel word die begrippe begunstiging en kliëntskap as 'n sosiaal-wetenskaplike model vir die verstaan van die vierde evangelie aangewend. Die doel van hierdie artikel is om aan die leser 'n nuwe begrip te bied wat andersins onontgin sou bly. Die teks van die vierde evangelie word vanuit een invalshoek onder ander invalshoeke gelees en daar word nie voorgegee dat elke segment van hierdie betrokke evangelie daardeur belig sal kan word nie. Daar word vanuit'n selektiewe invalshoek gefokus op sekere dele waarin die teks verlig word deur perspektiewe wat deur die beskermheer-kliënt model gebied word. So'n fokus beklemtoon juis die grootste geskenk wat Jesus Christus aan die mensdom gee, naamlik die gawe van lewe. Jesus gee namens die Vader, wie die uiteindelike beskermheer is, die seëninge van die koninkryk aan diegene wat in Hom glo. Terselfdertyd daag Jesus ook die aanvaarde model rakende die draagwydte van beskermheer-skap uit deur verskeie handelinge wat vir slawe gereserveer was, self te verrig, soos dit blyk uit die was van sy dissipels se voete.

\section{Introduction}

The use of social-scientific models to read the gospels, or aspects or episodes in the gospels, is increasingly found to be a fruitful enterprise. David Watson (2010) has recently used the honourshame culture of the Mediterranean world to investigate the messianic secret in Mark's gospel. Bruce Malina and Richard Rohrbaugh (1998:115-121) have written a commentary on the fourth gospel using the insights of social-scientific criticism. In this work, patronage is one of the models used to interpret the gospel, specifically John 5:21-30 where Jesus is depicted as 'God's honoured broker'. Tricia Brown (2003) also uses the social-scientific perspective to analyse pneumatology in John. To this end she makes extensive use of the patronage model in her analysis. In all these works the patron-client model is applied only to some sections, aspects or concepts in the fourth gospel. This article seeks to apply, heuristically, the patronage model to the whole gospel, exploring ways in which this reading can deepen and illuminate our understanding of the gospel.

The political setting of the events described in the fourth gospel is the Roman Empire where Rome, an overlord, rules the provincials, such as Judea and its environs, by means of client-kings. These kings got their position by virtue of being protégés of the Roman emperor. The Roman Empire lasted from 27 BC to AD 476, the peak of which was from 27 BC until AD 235 (Garnsey \& Saller 1987). Even the latest date projected for the writing of the fourth gospel by scholars ${ }^{1}$ is included in this period. However, it is pertinent to note that the groundwork for the socio-cultural context of the empire is traceable to the Roman Republic - the period between 508 BC and 27 BC.

\section{Historical background of patron-client relationships in the Roman Empire}

According to Karl-Joachim Hölkeskamp, the establishment of patron-client relationship is attributed to Romulus, the first king of Rome (Hölkeskamp 2006:491), who was said to have

1.The dates projected for the writing of the fourth gospel are as follows: C.K. Barrett (1978:109) proffers a date not later than AD 140 and not earlier than AD 90, whilst Raymond Brown (1966: LXXXVI) prefers AD $90-A D 100$ as the final form for the writing of the gospel. Craig Keener (2003:142) accepts a date in the nineties. 
'had the common people enrolled as clients of the leading men' (Deniaux 2006:401). A deeply stratified society where the nobility, the landowners, were distinct and separate from the common people who worked the land, patron-client relationship was a means of linking the two groups. Once a patron has adopted someone as a client, this relationship was passed on to the generations to come so that it became hereditary. Such social relations had the support of the law, which entailed that a patron or his family could not testify against a client or his relations in court, and vice versa. This means that the law formally recognised patronclient relationship and patrons who did not honour their relationship to their clients were liable to punishment (Deniaux ibid:401). The relationship is characterised by mutual obligation and mutual reciprocity tied to the honour or shame of the individuals or families concerned.

\section{Definitions}

According to Boissevain (1977), a patron-client relationship:

... is an asymmetrical, quasi-moral relation between a person (the patron) who directly provides protection and assistance (patronage), and/or who influences persons (clients) who depend on him for such assistance. Clients, in turn, provide loyalty and support when called on to do so. (p. 81)

\section{Key features of personal patronage}

1. Reciprocity: This means that the relationship is based on mutual reciprocity. At stake is the honour of each party in a context where being at the receiving end is considered shameful.

2. Asymmetry: This means that the relationship is between two unequal parties. Inequality exists in terms of status and in terms of goods that are exchanged.

3. Personal: The relationship in view is between two persons. Some scholars prefer to refer to it as a dyadic relationship. This stands in contrast to relationships between an individual and a group.

4. Voluntary: The relationship is entered to voluntarily, usually at the initiative of the client. Eilers is quite insistent that for it to be a true patron-client relationship the client has to take the initiative in asking to entrust himself to the patron, and the patron must consciously accept. This definitive act of entrusting oneself has been referred to as applicatio or deditio (Eilers 2002:32; Deniaux 2006:404).

\section{Types of patronage ${ }^{2}$}

The following types of patronage are distinguished:

Public patronage ${ }^{3}$ - a relationship in which a patron becomes the protector and benefactor of a group (for example, a craftsman's guild, a religious association, or even an entire city). Such patronage usually involves large gifts of money

2.Some scholars, like Deniaux, have often depicted the relationship between a freed man and his master as a form of personal patronage. Eilers disagrees with this for it can hardly be said to be a voluntary relationship - one of the conditions for the occurrence of personal patronage relationship.

3.Both Jonathan Marshall (2009:47-49) and Stephen Joubert (2000:63-66), for different though related reasons, consider this as euergetism [an act of benefaction] and not patronicium [an act of patronage]. Also see Alicia Batten (2008). for public buildings, alimentary schemes and public entertainment, but could also involve various forms of protection and advocacy.

Personal patronage - a relationship in which a patron aids an individual of lower status through money, gifts and dinner invitations, or helps with lawsuits or business affairs and other forms of advice and protection. Patron-client relationships might be maintained through several generations of the same families. ${ }^{4}$

\section{Obligations and duties of patrons}

Offering legal assistance, legal advice and legal protection was the 'most important duty of a patron' (Deniaux 2006:407; Eilers 2002:88-91), for private suits and public trials were quite common in the Roman society. Since the Roman law forbade payment for legal assistance, one's 'knowledge of the law, eloquence, and constant accessibility' (Deniaux ibid:408) was a sure means to shore up one's credentials as a patron 'to recruit new clients and to encourage new exchanges of services' (Deniaux ibid:408). The effect was an increase in the individual's prestige as he acquired a larger following because of his legal competence. The implication of this was that more people were under obligation to reciprocate his good gesture in the short or long run. In imperial Rome, the duties of patrons extended beyond legal assistance to encompass all of life, as Brown (2003) explains: ${ }^{5}$

... help their clients to procure citizenship, or get assigned to military commands or governmental offices, provide them with resources such as money, land or state-subsidized food and connections to important people. (p. 39)

\section{Obligations and duties of a client}

The obligations of a client towards a patron are allencompassing and not restricted to any one aspect of life. In the absence of a regular police force, clients provided security for their patrons, and in times of drought or scarcity of grain, the clients of a patron would provide enough grain so as to bring down the high cost of grain in the city the patron rules over (Deniaux 2006:411):

[Clients] contributed to the dowry of the patron's daughter, participated in collecting ransom for a patron who had been captured or a fine levied on a patron who had lost a suit, and shared his expenses of public office. (Deniaux 2006:402)

Gratitude was the single most important obligation of a client, and this was done best by publicising the good deeds of the patron. The expression of gratitude is found in stone inscriptions where the patron is eulogised and his good deeds listed for public knowledge (Brown 2003:39). In addition, clients left legacies for their patrons in their wills (Saller 1982:71).

4.Eilers moderates this view by saying that, though there are instances where patronclient relationship passes from father to son, this is not automatic and is not obvious from epigraphic inscries froms. Rather 'the Gris to not from epigraphic inscriptions. Rather, 'the Gracchan lex repetundarum assumes that the descendants of patrons and clients would remain amiable: this is why they cannot act as prosecutors or witnesses even if they were not themselves patrons
or clients' (Eilers 2002:79).

5.Eilers (2002:4-5) is of the view that the act of getting appointments or government positions is properly known as suffragium and appears sceptical to regard this as part of a patron-client relationship. 


\section{Categorisation of patrons: Patrons and brokers}

Jeremy Boissevain (1974) distinguishes between two categories of a patron's resources:

The first are resources, such as land, jobs, scholarship funds, specialized knowledge which [the patron] controls directly. The second are strategic contacts with other people who control such resources directly or have access to such persons. The former may be called first order resources, the latter second order resources. Persons who dispense first order resources may be called patrons. Those who dispense second order resources are brokers. (p. 147-148)

Brown (2003:29) further states that 'a broker facilitates communication between a patron who has specific resources and a client who needs the resources which that patron possesses'. To fulfil this function, a broker must represent the interests of both parties. He is in a unique position: though he serves as a sub-patron to the client, he cannot take the place of the ultimate patron.

The signals and cues within the fourth gospel that hint at patron-client relationships, will now be discussed.

\section{Hints of patron-client relationships in the fourth gospel}

\section{Introduction}

The fourth gospel shows traces that an understanding of patron-client relationship is one of the assumptions that underlie its writing and, therefore, its understanding. In addition, the Jesus of the fourth gospel seemingly advocates a complex web of patron-client relationships with his followers. These two positions will be discussed in turn.

Right from the start, there seems to be a castigation of the 'world' as an entity that failed to do obeisance, figuratively speaking, to its benefactor, logos. Extending the imagery of the Roman concept of patron-client, it could be said that the fact of creation has made logos a patron, ${ }^{6}$ in Roman parlance, and the world that he made his client. The reciprocity and the sense of obligation on the part of the world that should characterise the relationship is lacking, as John 1 tersely states:

He was in the world, and though the world was made through him, the world did not recognize him. He came to that which was his own, but his own did not receive him. (vv. 10-11)

The tenor for the conflict between the world and logos incarnate that would soon pervade the gospel is hereby set. From the perspective of a patron-client relationship, the blame is squarely put at the doorstep of the world - it was guilty of ingratitude, which was an unforgivable sin according to Cicero. In John 1:12 a contrast is seen as a group emerges that is in the world, but not of the world. The latter group is described as follows: 'to all who received him, to those who believed in his name, he gave the right to become

6.Patron here in the sense of a broker, for he came to broker peace between the creator and the world. In the prayer of chapter 17 , Jesus continues to extend a hand to the world to be reconciled with its maker. See John 17: 21,23 ('... so that the world may believe that you have sent me'). children of God' (Jn 1:12). For the group that accepts and believes in logos, the patron-client relationship brought about by creation deepens to something else that would later unfold in the gospel where it is stated (Jn 15:15): 'I no longer call you servants ... I have called you friends'. Yet, the patron-client relationship is still intact for 'no one gets to the father except by me' (Jn 14:6). ${ }^{7}$ This curious distinction between servants or clients and friends is instructive of the disrepute into which the term cliens had fallen. Some scholars have denied the prevalence of patron-client relationship on account of the fact that the term was not used in literature. But, as Saller (1989:52) has pointed out: 'cliens certainly carried connotations of social inferiority, and, as a result, aristocratic authors most often used it with reference to "humble men"'. Saller (ibid:52) notes that 'some Romans think it as bitter as death to have accepted a patron or to be called clients'. If Saller's observation is true, then the term cliens had become quite derogatory, and this perhaps explains the sparce reference to it in literature. The term amici [friends] was then more widely used. The term amici however soon became differentiated, as Saller (1989) puts it quite succinctly:

Though willing to extend the courtesy of the label amicus to some of their inferiors, the status-conscious Romans did not allow the courtesy to obscure the relative social standings of the two parties. On the contrary, amici were subdivided into categories: superiors, pares and inferiors (and then lower down the hierarchy, humble clientes). (p. 52)

A Latin translation would render friends as amici and this would highlight all these possibilities of friendship amongst equals, or with a superior or an inferior.

\section{Dualism}

The fourth gospel, in contradistinction to the synoptic gospels, is notable for its use of dualism such as light vs. darkness, life vs. death, heaven vs. earth, and above vs. below. The notion of dualism as found in the gospel is crucial, for it emphasises the transcendence of God to the world he has made. In patron-client terms, it shows that God and humans do not belong to the same class (asymmetry). This scenario makes the agency of Jesus, the God-man, as the broker or the intermediary between God and humanity inevitable (Piper 2001). By employing the literary device of dualism the writer of the fourth gospel, one may surmise, sets the stage for the brokerage of Jesus and hence a patron-client reading of the gospel.

\section{The 'calling' of the disciples}

The fourth gospel presents a unique Roman patron-clientinclined method of the 'calling' of the disciples that is quite unlike the account of the synoptics. Whilst in the synoptic gospels we see Jesus calling on certain people to become his disciples, the fourth gospel shows the would-be disciples, with the exception of Phillip, showing up literarily at the 'doorstep' of Jesus in a true clientelistic fashion. According to Deniaux, an individual could make a request to enter a state of clientship voluntarily. Such a request is called applicatio

7.Phillip's attempt to bypass Jesus and have a direct access to the father is denied (cf. Jn 14: 8-9). 
or commendatio, which means an act of entrusting oneself to someone else. Andrew Drummond (1989:101) concurs with this view by saying that patron-client relationships usually occur at the instigation of the client. ${ }^{8}$ The uniqueness of the 'calling' of the disciples lies in the fact that it was at the recommendation of someone. Andrew came to Jesus at the recommendation of John the Baptist, Peter came at the recommendation of Andrew, and Nathaniel came at the recommendation of Phillip. In this manner, they served as brokers linking their 'clients' to the patron, Jesus.

\section{Other patrons and brokers in the fourth gospel}

The fourth gospel seems to identify other people who could act as brokers, but soon puts such claims to rest. Perhaps the strongest possible claims are John and Moses. ${ }^{9}$

\section{John the Baptist}

The fourth gospel goes to great lengths to demonstrate that John is not the broker. At best he appears as someone who introduces clients to Jesus and then fades out of the scene. John the Baptist is described merely as a witness to the light and not the light himself (Jn 1:8). John the Baptist of the fourth gospel openly declares his inferior position that he is not the Christ (Jn 1:15, 20, 26-27, 29). The demotion of John as a would-be patron seems complete when two of his disciples transfer their allegiance to Jesus (Jn 1:37). At best, 'John is, in a sense, sent from God as a broker. He brokers access to Jesus by revealing him to Israel' (Brown 2003:80). But once he accomplishes this he disappears from the scene. The fact that he does not continue as a broker implies that he was, as he called himself, a voice and not a broker.

\section{Moses}

Moses is a more formidable contender for the role of a broker as portrayed by the Pharisees. Right from the first chapter of the fourth gospel the scene is set for what would later follow in the gospel. Moses is compared with Jesus in a contrastive manner: 'the law was given through Moses; grace and truth came through Jesus Christ' (Jn 1:17). In an apparent repudiation of the fame of Moses as one 'who spoke face to face with God' (Ex 33:11), and the one who saw the back parts of God (Ex 33:21-23), the fourth gospel says that no one has ever seen God except the only begotten one of God who lies at the bosom of the father. ${ }^{10}$ In a context where eyewitnesses' accounts were highly valued in judging matters, the writer of the fourth gospel suggests that the profile of Jesus as a broker is more credible than Moses' profile. Yet, this is just but a hint of how the matter may be resolved later, for the disciples of Moses (Jn 9:28) carried on the contention until they got Jesus killed.

8. However, Tricia Brown (2003:110) notes that it is quite honourable for patrons to seek out clients. Claude Eilers (2002:25) is quite clear that 'patron-client relationship was formed at the request of the client.

9.For the Samaritan woman it would be Jacob: 'are you greater than our father Jacob?' (Jn 4:12)

10.Draper (2004:164) argues that the one Moses saw was Jesus, for 'no one could see God and live' (Ex 33:20; cf. Draper 2008). See a similar view expressed by A.T. Hanson (2006:21).
In the instances cited above, where John and Moses acted as would-be brokers, the writer of the fourth gospel affirms Jesus as the only credible broker. Arguing from another perspective, Buck (1972) says:

John's extreme christology (christus solus) allowed for no other centres of interest, let alone rival sects. In his zeal, John was suspicious even of the figure of the Mother of Christ, who later developed into the Mother of God. (p. 172)

\section{The role of Jesus}

The ambiguity that characterises Jesus' role as a broker or as a patron is found right from the first verse of the fourth gospel. The relationship between logos, who is also referred to as God, and God (a distinct being) is not explained, but assumed in this verse. As noted above, logos is a patron to the world by virtue of creation. An interesting twist comes in verse 13 of the first chapter, for those who accept the patronage of logos are curiously not called the children of the word, but the children of God. Verse 14 explicitly states that the word, having become enfleshed, has its origin in God. Perhaps this is a key to understanding the concept of the patron or broker role of Jesus in the fourth gospel - the word's descent to the world puts him in a role that affords him to be the link between God and humanity, for he now shares a relationship with both parties. As the word he was a patron to the world, and becoming a citizen in the world (though not of the world), the prospective clients would be more at home with him and he could serve them better as a broker.

\section{Jesus' brokerage and christology in the fourth gospel}

Reading through the fourth gospel, it is clear that Jesus is unequivocally presented as a broker in the fourth gospel. A broker, as defined by Boissevain (1974:147-148), dispenses 'second order resources' for he or she is in 'strategic contact with other people who control such resources directly or have access to such persons'. Ultimate patrons on the other hand have direct control over the resources. A broker is effective to broker goods and services to his clients based on the degree of his intimate relationship with the patron. To this end, the Jesus of the fourth gospel makes reference to himself as someone sent by God, as someone who speaks what God asked him to speak (Jn 12:49), as someone who obeys his father, and as someone intimate with God. God shows him everything (5:20), and everything the father has belongs to him (16:15). His intimate relationship with God is consistently presented throughout the whole gospel. He is the one who had been with God at the beginning. As logos, he is God's agent in creation. He is the one that was at the bosom or side of the father (1:18). Because of this, he is matchless: Moses could not compete with him (1:17), Abraham paled into insignificance before him ('before Abraham was I am' (8:58)). Nicodemus (3:2) acknowledged him as the teacher who came from God, for no one could do the miracles that he did unless God was with him. The Samaritan woman's attempt to compare him with Jacob who dug a well for them was met with a greater claim when Jesus said (4:14): 'the water 
I will give you will become a well in you springing to eternal life'. The man born blind (Jn 9:32-33) asserts that 'nobody has ever heard of opening the eyes of a man born blind, if this man were not from God he could do nothing'. The intimate relationship that Jesus has with the father assumes a unique degree of unity as to suggest equality ('my father and I are one' (Jn 10:30)), resulting in the high Christology we have in the fourth gospel. Brown's (2003) comments are instructive at this point:

Jesus' greatest advantage over other purported brokers to God is his heavenly origin and his ability to claim for himself the

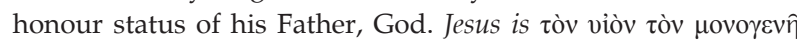
[the only begotten son] and thus can claim an edge over all other brokers ... The effectiveness of Jesus' brokerage depends entirely on his unique ability as God's Son to mediate access to God (p. 95).

\section{Gifts and obligations in patron-client relationship in the fourth gospel}

\section{Benefits of Jesus' brokerage}

As in every patron-client relationship there are gifts (beneficia) that the patron should bestow on his clients. The terms beneficium, officium and meritum, according to Saller (1982:15-21), are the favours which parties involved in patron-client relationships bestow on each other. ${ }^{11}$ The gifts and favours that Jesus is able to get for his clients are dispersed throughout the gospel. They range from the right to become children of God (Jn 1:12), eternal life (Jn 3:15, 6:40, 17:2), baptism of the Holy Spirit (Jn 1:33, 14:16), and his name (Jn 16:23-24). ${ }^{12}$ However, the ultimate and encompassing gift that Jesus brokers for his clients is eternal life, as John 10:28 says: 'I give them eternal life, and they shall never perish'.

\section{The responsibilities and duties of the clients}

The clients on their part were required primarily to believe in him. The theme of belief runs through the whole of the gospel: from 'to all who received him, to those who believed in him' (Jn 1:12), through to the proclamation by Thomas: 'my Lord and my God' (Jn 20:28). In between these two are accounts of those who accepted him (Jn 4) and those who rejected him (Jn 8:58-59), leading ultimately to his crucifixion.

\section{The role of signs}

The signs that Jesus performed do not function as gifts (beneficia) to clients, but as a form of the Roman commendationes. Brokers' success does not only hinge on how well related or intimate they are to the holders of primary resources, but on the fact that their well-connectedness is public knowledge. Jesus' intimate relations with the father would not make him a broker unless this knowledge is made known to the public. The signs performed by Jesus, in this light, were meant to bring him to public notice as one approved by God and by this means have people repose their confidence in him. Strictly

11. However, Deniaux (2006:405) defines beneficia as favours bestowed by a patron and officia as marks of gratitude by a client. I follow Saller's more convincing argument that in terms of usage as an act of generosity, there is an overlap in their meaning.

12.Brown (2003:105) has a longer catalogue than these. speaking, commendationes are recommendations written by a broker on behalf of his client to a patron. It is in this light that John the Baptist's testimony of Jesus introduces Jesus to the people. In a monologue in chapter five, Jesus acknowledges John's testimony, but considers the testimony of the 'works' greater than John's. The episode of the feeding of the 5000 by Jesus perhaps best illustrates the understanding of signs as commendationes. After feeding them, the crowd wanted to forcefully make Jesus a king, ${ }^{13}$ but he quickly withdrew from them. The following day, the crowd found him after much searching and Jesus mildly rebukes them for seeing the feeding as an end in itself and not just a commendatio.

\section{The role of the parakletos}

The relationship of Jesus with his disciples becomes more complex at his imminent departure. The parakletos is depicted as coming at the instance of Jesus' intercession to the father as found in John 14:16, or is depicted as coming at the direct instance of Jesus as found in John 16:7. It is clear that the parakletos cannot be received without the intervention or influence of Jesus. The paraclete, as a broker, 'provides access to Jesus after Jesus' departure' (Brown 2003:61). He will remind them of the words Jesus had spoken to them (Jn 14:26), he will testify of Jesus (Jn 15:26), he will guide the disciples into all truth (Jn 16:13), and he will glorify Jesus (Jn 16:14). The paraclete therefore effectively becomes the broker between the believers and Jesus after his ascent to heaven. The parakletos mediates God's presence to his people on earth.

\section{Reading some episodes in the fourth gospel in light of the patron- client model}

The episodes listed below are accounts in the fourth gospel where a patron-client model will illuminate the readings.

\section{A patron-client reading of Jesus' discourse with the Samaritan woman in John 4}

Jesus opens up conversation with the Samaritan woman by asking for water to drink, thereby opening himself up to receiving a beneficium from the woman and, in patronclient parlance, asking to be her client. The woman was quite reluctant, and rightly so, because he had no commendatio to recommend him to her and moreover, the long-standing enmity between Samaritans and Jews could not be overcome so quickly. This is an illustration of the fact that the patronclient relationship is based on friendship: one must be or be seen as a friend or a friend of a friend for the relationship to commence. Jesus' counter to the woman's antipathy is an offer of a beneficium: the offer of living water. At this moment in the narrative, the roles change, with Jesus becoming the patron. Jesus got the attention of the woman, for she did need water. The question that however remained was how could she trust this stranger? On what basis could he offer what Jacob, their patron, never gave? Although Jacob had

13.This will suggest making Jesus the ultimate patron and not just a broker. It is, perhaps, a deliberate piece of irony that the charge for killing Jesus was that he was king of the Jews, a title he had rejected. 
dug a well for the community, Jesus contrasts what he will give with what Jacob gave. Nobody needs a new patron if the old one satisfies all the needs of the client. As the woman was aware, she always needed to come to the well to draw water because the satisfaction provided by the well was only temporary. Jesus promises to give water that has the propensity to become a spring of water in that person and for this reason the person is never ever thirsty again. In contrast to Jacob's temporary solution to thirst, Jesus' solution lasts till eternity. Having heard the appeal, or commendatio, the woman was ready to switch sides and change patrons. To strike home the appeal, and perhaps to disengage the mind of the woman from mundane issues of water and drinking, Jesus asks more personal questions which eventually culminate in Jesus revealing himself as the expected Messiah. At the return of Jesus' disciples, the woman leaves, but only, as could be expected from a good client, to proclaim the noble character of her patron to her community. Many Samaritans accepted Jesus as their patron (verse 39), and in this way the woman became a broker. However, as is usual in the fourth gospel, the woman was no longer needed as a broker; her commendationes had paid off. The Samaritans could then say (Jn 4:42): 'We no longer believe just because of what you said; now we have heard for ourselves and we know that this man really is the saviour of the world.

\section{The triumphal entry}

The account of Jesus' triumphal entry into Jerusalem in John 12 is the last public act of Jesus before his arrest and passion. This account, much like the synoptics' account of Jesus' cleansing of the Temple, is strategically placed in the narrative. It is an act that made the charge of being 'the king of the Jews' stick on Jesus. I would suggest that it was a calculated political move with the goal to have political resonance in the mind of the authorities. This is amply demonstrated by the fact that patrons in imperial Rome made themselves visible as men of substantial support by striding around town with a large following. The larger the following, the greater the prestige of the patron and the louder the signal this sends to the authorities of someone that cannot be ignored by virtue of his following. Because power was concentrated at this time in the hands of the emperor, the emperor sought to do acts that would get him the greatest accolade. This was best done by giving honour or being known as a friend of someone with a large following. The patron's followers would feel honoured and would publicise the patron's good deeds.

I am of the opinion that Jesus made a political statement that was sure to get him noticed by the local authorities who had feared his soaring popularity. This is borne out by the statement in verse 19: 'So the Pharisees said to one another, see this is getting us nowhere. Look how the whole world has gone after him'. This insight can be combined with the limited goods understanding of the society and this leads one to know why Jesus got into trouble with the honourable ones of his day. Limited goods worldview posits that the amount of desirable goods or honour in society exist in limited quantity. One, therefore, gains honour or goods at the risk of someone else (Esler 2000:18-19; Malina 1987). So as Jesus increased in honour, the honourable ones of his day decreased in honour or perceived themselves so to be, just as John said: ' $[H]$ e must increase and I must decrease'. However, unlike John, their reaction was to seek to be rid of him.

\section{Jesus: The door of the sheep (Jn 10:7, 9)}

One of the 'I am' statements that portrays Jesus as a broker is John 10:9: 'I am the door, anyone who enters through me will be saved'. Spoken in the context of the blind man that was thrown out of the synagogue (Jn 9:35), Jesus states that the benefits that accrue to the sheep for passing through the door are salvation and pasture. These two related themes of salvation and provision of pasture are the promises made to the exilic community that suffered from selfish and greedy leadership in Ezekiel 34:12-13: 'I will rescue them ... I will pasture them'. Jesus is bringing the promise of the father to a similar group that suffers rejection by its leaders. Jesus, therefore, brokers the gifts of the father to this excluded group. The contrast introduced in verse 8 with 'those that came before me' suggests the sole brokerage of Jesus, namely that no one else could legitimately guarantee or give the sheep salvation or pasture. Salvation and pasture signify eternal life as the benefit derivable from the brokerage of Jesus.

\section{Jesus and the father (Jn 10:15, 17, 18)}

The fourth gospel is notable for its depiction of the relationship between Jesus and God as son-father relationship. Dunn (2006:233) carefully observes that this is a pervasive theme in the fourth gospel and it stands in contradistinction to the synoptic gospels. The unique love relationship between the father and Jesus is critical to Jesus' ability to function as a credible broker between the people and God. As noted above, brokers do not dispense their own resources, but use the influence of their relationship with the ultimate patron to allocate resources or gifts to the clients. Jesus' unique relationship with the father is attested to by the phrase (Jn 10:15): 'the father knows me and I know the father'. The verb translated 'to know' here is ginooskoo and it depicts knowledge based on 'direct personal experience' (Louw-Nida I 27.8). This personal relationship guarantees the efficacy of the brokerage of Jesus. Whilst modern scholars such as Terry Johnson and Christopher Dandeker (1989:223) have separated kinship ties from patron-client relations, this is often not so in traditional societies. ${ }^{14}$ Instances abound in the Roman society where the sons or wife of the emperor served as brokers that linked their clients to the emperor, the ultimate patron. ${ }^{15}$ The mutual love, trust and understanding between the father and Jesus enables the father to permit Jesus the choice of laying down his life, or of withholding

14.Augustine Agwuele (2009:41) argues that amongst the Yoruba of West Africa, appeal is often made to kinship ties or relationships by prospective clients in order to attract patronage. In addition, see Daniel Jordan Smith (2001). Caroline Bledsoe (1980:58) says the following of an ethnic group in Liberia: '[ $/$ n Kpelle society kinspeople do enter into relations that are best described as patron-client
relations'.

15.Often cited is Livia, the wife of Augustus, who served as a broker between her many clients and Augustus (her husband), and later Tiberius (her son). See Brown, (2003:32-33). 
it (labein, v. 18). Jesus adequately represents the interest of the father for he chooses what pleases the father - the laying down of his life (v. 17). This singular act makes Jesus a most effective broker. In this way, Jesus critiques the ordinary patron-client relationships of the Roman Empire, for by his readiness to lay down his life Jesus demonstrates that the lives of the disciples were precious to the father, as well as to himself. A patron-client relationship, as aforementioned, is essentially between individuals of unequal status. The client, who is of lower status, seeks by all means to enhance the status or honour of his patron. ${ }^{16}$ Jesus' act of laying down his life could be considered as a lowering of status and through this act of self-denial, that is quite unexpected of a broker, Jesus reverses the anticipated role of a broker.

\section{A patron-client reading of Jesus' prayer for the disciples in chapter 17}

Unlike the Jesus in the synoptic gospels, the Johannine Jesus hardly prays. The fourth gospel narrates three instances when Jesus prayed. The first is when he gave thanks over the five loaves of bread and the two small fish that he used to feed a multitude of people as found in chapter 6 . A second occasion is his prayer at the graveside of Lazarus in chapter 11 just before he raised him from the dead. The prayer of Jesus in chapter 17 is the third instance. Jesus' prayer in this chapter is a petition on behalf of his disciples and those who would later believe in him through their testimony. Although Jesus prays for himself as well in chapter 17, our focus here is his prayer for his disciples. The prayer is pivotal on a number of accounts: it confirms Jesus' role as a broker and it shows that the concept of eternal life is the central mission of Jesus' ministry according to John's gospel.

\section{Confirmation of Jesus as a broker}

Reading with patron-client lenses, it is instructive to note that the prayer of Jesus can be seen as commendatio that Deniaux (2006:405) defines as an 'act of entrusting'. Saller (1982) argues against the notion that commendationes served as confidential reports that the emperor consulted in making appointments. He argues that though commendationes often mention some attributes of the client, these attributes were too general to guide the emperor in judging the suitability of the client. Rather, what often happened was that the decision of the patron was informed by his relationship with the broker on the one hand and by the relationship of the client with the broker, as described in the commendatio, on the other hand. In this regard, commendationes often describe the relationship between the broker and the client. In this way, 'the recommender illustrates his client's loyalty, integrity and industry by reference to his display of those qualities in their mutual friendship' (Saller ibid:109). The point being made here is that the patron, having known the broker, could judge what to expect from any friend of his, for as Saller (ibid:109) says: '[I]n the Roman view a man's character was reflected in his friends'. Saller (ibid:110) in addition notes

16.According to Garnsey and Saller, clients call at the homes of their patrons in the morning, for morning greeting known as salutatio, see Garnsey and Salle (1987:122). that commendationes are usually made in person and not by letter. ${ }^{17}$ Therefore, we shall note to what extent Jesus' prayer conforms with or departs from the pattern of commendationes in the Roman Empire. Some of our English translations, like the New International Version, have rightly interpreted Jesus' speech here as prayer, but it is instructive that the Greek literally reads: 'Lifting his eyes into heaven he said...' So here we have a direct address as if Jesus was appearing in person before the ultimate patron to make recommendation, or commendatio, on behalf of his disciples, his clients. One departure from ordinary commendationes that we may observe is that the commendatio was taking place when the clients were present. More or less five related issues are discernible in the prayer, which will be discussed below.

\section{Jesus' relationship with the father}

The intimate relationship between Jesus and the father is depicted in various ways:

- In verse 11 we read that the patron had given the broker his name.

- Verse 24 states that the patron loved the son before the creation of the world.

- Verse 10 says all that the patron has belongs to the broker and all that the broker has belongs to the patron.

- In verse 1 Jesus refers to himself as the son and the patron as the father.

Brown (2003:32-33) refers to instances where members of family serve as brokers linking their clients to a patron, who is their own blood relation. Jesus makes recourse to their long-standing relationship by referring to the glory he had with the father before the world began (verse 5). As mentioned earlier, the success of a broker lies in the strength of his intimacy with the patron and Jesus is here enumerating this strong relationship.

\section{Commendation of the disciples}

Jesus recommended the disciples to the father by highlighting what they believed and have done:

- In verses 6 and 8, the clients are said to have obeyed God's word.

- In verses 7 and 8 the clients know that the patron is the source of all that the broker (Jesus) has.

- Verse 8 states that the clients have accepted the words that the broker gave them and these are words that the patron gave the broker in the first place.

- Verses 8 and 25 say the clients are certain that the broker came from the patron.

- In verse 10 we read that all that the patron has belongs to the broker and all that the broker has belongs to the patron.

- Verse 9 affirms that the clients belong to the patron.

- Verse 10 states that the clients have brought glory to the broker.

Jesus's prayer presents the clients as people worthy of the patron's patronage on the strength of their relationship with the broker.

17.This is one reason for the paucity of literature on such acts. 


\section{Critique of existing patron-client relations in the fourth Gospel}

We have seen how the fourth gospel makes use of the patronclient relations in its context to illuminate the relationship of Jesus with his disciples and the father. It is, however, instructive to note how the writer of the fourth gospel also subverts the popular notions of patron-client relations in the gospel.

\section{Sole brokerage}

In contrast to what was obtained in Roman patron-client relations, where a client may have more than one broker or patron, this is not so in the fourth gospel. The fourth gospel advocates for the sole brokerage of Jesus. This is because the goods of the kingdom, which is primarily eternal life, is found only in Jesus. Whilst some, like John the Baptist and Mary, introduced others to Jesus, they did not remain a link between the people and Jesus. We therefore see Jesus of the fourth gospel maintaining a direct relationship with his followers, with all other brokers out of the picture.

\section{Feet washing}

Jesus' act of washing the feet of his disciples, as found in chapter 13 , is inexplicable by the patron-client model, but yet it is presumed by it. Whilst patrons could do a myriad of things for their clients, washing their feet was definitely out of the question. Washing of feet was the preserve of slaves. That patron-client relationship presumed by the text is evinced by Peter's consternation at this act and Jesus' statement (Jn 13):

You call me 'Teacher' and 'Lord', and rightly so, for that is what I am. Now that I, your Lord and Teacher, have washed your feet, you also should wash one another's feet. (vv. 13-14)

Jesus in this way subverts the popular notions of patronage and affirms that true patronage as an asymmetrical relationship is about service rendered on behalf of the weak, poor or people of lower status to form a fictive kinship relationship.

\section{Conclusion}

Reading the fourth gospel through the lens of the patronclient model has demonstrated the portrayal of Jesus as a broker in the gospel. The fourth gospel skilfully does this by ascribing to Jesus a unique and matchless relationship with the father, thereby submitting that he is the only one fit to be a broker. The dualism evident in the gospel is strategic, for it creates the context for the need of a broker. This reading is both an affirmation and a critique of the patron-client model. In a world polarised along the lines of gender, race, wealth and status, a patron-client reading of the fourth gospel offers hope that, since the greatest dualism (between heaven and earth) has been bridged by Jesus, God's broker, all other dividing lines could be bridged by those whom he sent just as the father had sent him.

\section{Acknowledgments Competing interests}

The author declares that she has no financial or personal relationship(s) that may have inappropriately influenced her in writing this article.

\section{References}

Agwuele, A., 2009, 'Popular culture of Yoruba kinship practices', in T. Falola \& A. Agwuele (eds.), Africans and the politics of popular culture: Rochester studies in African history and the Diaspora, pp. 41-63, University of Rochester Press, New York. Barrett, C.K., 1978, The gospel according to St John, SPCK, London.

Batten, A., 2008, 'God in the letter of James: Patron or benefactor?', in J.H. Neyrey \& E.C. Stewart (eds.), The social world of the New Testament: Insights and models, pp. 49-61, Hendrickson/Peabody, Massachusetts.

Bledsoe, C., 1980, Women and marriage in Kpelle society, Stanford University Press, Stanford.

Boissevain, J., 1974, Friends of friends: Networks, manipulators and coalitions, Blackwell, Oxford.

Boissevain, J., 1977, 'When the saints go marching out: Reflections on the decline of patronage in Malta', in E. Gellner \& J. Waterbury (eds.), Patrons and clients in Mediterranean societies, pp. 81-96, Duckworth, London.

Brown, R.E., 1966, The gospel according to John (I-XII), Doubleday, Garden City.

Brown, T.G., 2003, Spirit in the writings of John: Johannine pneumatology in socialscientific perspective, T\&T Clark, London.

Buck, H.M., 1972, 'Redactions of the fourth gospel and the mother of Jesus', in D.E. Aune (ed.), Studies in New Testament and early Christian literature: Essays in honor of Allen P. Wikgren, pp. 170-180, E.J. Brill, Leiden.

Deniaux, E., 2006, 'Patronage', in N. Rosenstein \& R. Morstein-Marx (eds.), A companion to the Roman Republic, pp. 401-420, transl. R. Morstein-Marx \& R. Martz, Blackwell, to the Roman Republic, pp. 401-420, transl. R. Morstein-Marx \& R.

Draper, J.A., 2004, 'Practising the presence of God in John. Ritual use of scripture and the eidos theou in John 5:37', in J.A. Draper (ed.), Orality, literacy, and colonialism in antiquity, pp. 155-168, Society of Biblical Literature, Atlanta.

Draper, J.A., 2008, “"The law came through Moses. Grace and truth through Jesus Christ": yes please, you may delete (John 1:17). Moses and the Sar Harpanim in Jewish mystical speculation', paper presented at the NTSSA conference, Hammanskraal, 15-18 April.

Drummond, A., 1989, 'Early Roman clients', in A. Wallace-Hadrill (ed.), Patronage in ancient society, pp. 89-115, Routledge, London.

Dunn, J., 2006, The parting of the ways: Between Christianity and Judaism and their significance for the character of Christianity, SCM, London.

Eilers, C., 2002, Roman patrons of Greek cities, Oxford University Press, London. http://dx.doi.org/10.1093/acprof:0so/9780199248483.001.0001

Esler, P., 2000, 'The Mediterranean context of early Christianity', in P.F. Esler (ed.), The early Christian world, pp. 3-25, Routledge, New York.

Garnsey, P. \& Saller, R., 1987, The Roman Empire: Economy, society and culture, Duckworth, London.

Hanson, A.T., 2006, The prophetic gospel: A study of John and the Old Testament, T\&T Clark, London.

Hölkeskamp, K-J., 2006, 'History and Collective Memory in the Middle Republic', in N. Rosenstein \& R. Morstein-Marx (eds.), A companion to the Roman Republic, pp. 478-495, Blackwell, Massachusetts. http://dx.doi.org/10.1002/9780470996980.ch23

Johnson, T. \& Dandeker, C., 1989, 'Patronage: Relation and system', in A. WallaceHadrill (ed.), Patronage in ancient society, pp. 219-242, Routledge, London.

Joubert, S., 2000, Paul as benefactor: Reciprocity, strategy and theological reflection in Paul's collection, Mohr Siebeck, Tubingen.

Keener, C., 2003, The gospel of John, Hendrickson, Peabody.

Malina, B., 1987, 'Wealth and poverty in the New Testament and its world', Interpretation 41 (4), 354-367.

Malina, B. \& Rohrbaugh, L., 1998, Social-science commentary on the gospel of John Fortress Press, Minneapolis. http://dx.doi.org/10.1177/002096438704100403

Marshall, J., 2009, Jesus, patrons, and benefactors, Mohr Siebeck, Tubingen.

Piper, R., 2001, 'Glory, honor and patronage in the fourth gospel. Understanding the doxa given to disciples in John 17', in J.J. Pilch (ed.), Social scientific models for interpreting the bible, pp. 281-309, Brill, Leiden.

Saller, R.P., 1982, Personal patronage under the early empire, Cambridge University Press, Cambridge.

Saller, R.P., 1989, 'Patronage and friendship in early imperial Rome: drawing the distinction', in A. Wallace-Hadrill (ed.), Patronage in ancient society, pp. 49-62, Routledge, London. http://dx.doi.org/10.1017/СBO9780511583612, PMid:7173312

Smith, D.J., 2001, 'Kinship and corruption in contemporary Nigeria', Ethnos 66 (3), 344-364. http://dx.doi.org/10.1080/00141840120095131

Watson, D., 2010, Honor among Christians: the cultural key to the messianic secret, Fortress, Minneapolis. 